\title{
INFLUENCE OF DIETARY HABITS OF UNIVERSITY STUDENTS ON BODY MASS INDEX (BMI) (A COMPARATIVE STUDY AMONG EGYPT AND SAUDI ARABIA AND TURKEY)
}

\author{
Üniversite Öğrencilerinin Beslenme Alışkanlıklarının Beden ve Kitle İndekslerine Etkisi \\ (Türkiye, Mısır ve Suudi Arabistan Arasında Karşılaştırmalı Bir Çalışma)
}

\author{
Hala Hassan EI Sayed ${ }^{1}$ \\ Mona Mohamed El-Shafei ${ }^{2}$ \\ Lokman Toprak ${ }^{3}$ \\ ÖZET
}

Ergenlerde görülen beslenme alışkanlıkları ve uygulamaları veya yeme alışkanlıkları onların sağlı̆̆ı üzerinde olumsuz sonuçlar doğurabilmektedir. Alkolsüz içecekler, tatlı içecekler, fast food tüketiminin aşırı düzeylere varması alımı, meyve, sebze, tam tahıllı gıdalar, süt ürünleri ve diğer kalsiyum katkılı gıdaların yetersiz alımı; düşük düzeylerde egzersiz yapımı ile artan obezite oranları ile ortaya çıkan olumsuz sağlık sonuçları; bu yaş grubunun beslenme ve yaşam tarzı özelliklerini yeniden gözden geçirmelerinin bir ihtiyaç olduğunu göstermektedir. Bu çalışma Mısır, Suudi Arabistan ve Türkiye arasında karşlaştırmalı bir araştırma olarak farklı kültürlerde ağırlık fazlalı̆̆ı ya da eksikliğinde (BMI) üniversite öğrencilerinin beslenme alışkanlıklarının etkisini belirlemeyi amaçlamaktadır. Bu araştırma 450 öğrencinin (her bölgeden 150) beslenme alışkanlıklarını ortaya çıkaracak bir anket formu kullanılarak gerçekleştirilmiştir. BMI (ağırlık / boy2 $\mathrm{kg} / \mathrm{m}$ 2) ölçülmüş (tüm ölçümler çalışma bölgelerinde de aynı koşullar altında alınmıştır) ve göreceli ağırlık endeksi olarak kullanılmıştır. Sonuçlar Suudi Arabistanlı öğrencilerin yaklaşık yarısının (\% 43.33) kilolu, Türkiye'deki numunelerin çoğunluğunun (\% 75.3) normal kilolu olduğunu, Mısır'da ise özellikle kadın katılımcıların 50.67\%'sinin kilolu olduğunu ortaya koymuştur. Öte yandan sonuçlar; bütün faydalarına rağmen kahvaltının en sık atlanan öğün olması gibi üniversite öğrencileri arasında pek çok sağlıksız beslenme alışkanlıkları olduğunu ortaya koymaktadır. Çalışma, üniversite öğrencilerinin beslenme alışkanlıklarını değiştirecek, sağlıklı gıda ve diyet çeşitliliğini tanıtacak; eğitim programları önermektedir.

Anahtar Kelimeler: Beslenme alışkanlıkları, Ergen - Vücut Kitle İndeksi (BMI)

\begin{abstract}
Dietary habits and practices or eating habits observed in adolescents may have detrimental consequences on their health. The adverse health consequences that may result from excessive intake of soft drinks, sweet drinks and fast foods consumption; inadequate intake of fruits, vegetables, whole grain foods, dairy products and other calcium-fortified foods; reduced levels of exercise ; and increasing obesity rates indicate a need to revisit the diet and lifestyle characteristics of this age group. This study aims to determine the effect of dietary habits of university students on the weight excess or deficiency (BMI) in different cultures as a comparative study among Egypt, Saudi Arabia and Turkey. A survey was carried out using a questionnaire to consider the dietary habits of 450 university students (150 from of each region). BMI (weight/height2, $\mathrm{kg} / \mathrm{m} 2$ ) was measured (all measurements were taken under the same conditions at study regions) and used as index of relative weight. The results indicated that $50.67 \%$ of participants in Egypt, especially female students, were overweight while nearly half of Saudi Arabian students (43.33\%) were underweight and the majority of the sample in Turkey (75.3\%) was normal weight. On the other hand the results found many of dietary habits which lead to unhealthy bodies among the university students like most often skipped breakfast despite its all benefits. The study suggested that increasing of educational nutritional programs which introduce healthy pattern of food and diet will improve the dietary habits of university students.
\end{abstract}

Key words: Dietary habits - Adolescents - Body Mass Index (BMI)

\footnotetext{
${ }^{1}$ Prof. Dr., Department of Tourism and Hotel Management, Mardin Artuklu University, Turkiye

${ }^{2}$ Asst. Prof., Community Health Sciences Department College of Applied Medical Sciences, King Saud University

${ }^{3}$ Asst. Prof., Department of Tourism and Hotel Management, Dicle University, Turkiye
} 


\section{Conceptual definitions:}

\section{Dietary habits:}

Dietary habits are the habitual decisions an individual or culture makes when choosing what foods to eat. (From Wikipedia, the free encyclopedia)

\section{Adolescence:}

The World Health Organization (WHO) defines 'adolescence' as the age between 10-19 years old (WHO, 1997). In the same line, the Centers for Disease Control an Prevention (www.cdc.gov) define adolescence as 12-19 years old, but they often group adolescents and young adults (20-24 years old) together (NCHS, 2005).

\section{Body mass index (BMI)}

Body mass index is defined as the individual's body mass divided by the square of his or her height. The formulae universally used in medicine produce a unit of measure of $\mathrm{kg} / \mathrm{m}^{2}$. (Eknoyan, Garabed 2007)

\section{Introduction:}

The formative years of adolescence represent a crucial stage in the human life cycle since it is the stage when lifestyles are formed and become established. During this period, adolescents become more independent and have increased access to food choices apart from those available at home. It is also in this period when the social interactions with peers increase and adolescents develop individual eating habits and physical-activity patterns. Dietary habits appear to be established in the mid-teens and were shown to be closely associated with lifestyle (Sweeting H et,al.,1994). On the other hand, adolescents are often not concerned about health problems they may develop later in life and although they may have notion of health related benefits of healthy eating and physical activity, evidence suggests that this is not being translated into action (WHO, 1997). Nowadays media affects attitudes about body weight which leads adolescents to have unhealthy eating habits (Heilman, E.1998). A better understanding of the relationship between healthy behaviors among young people is considered necessary for effective prevention and management of lifestyle-related risk factors.

Knowledge about healthy food choices and food safety can be a predisposing factor for improving eating habits and adopting a healthy diet (Prell HC.et.al.,2005) although it is insufficient to motivate healthy eating (Niciforovic-Surkovic O. 2002). Factors influencing eating behaviors need to be better understood to develop effective nutrition interventions tailored to individuals to improve their healthy eating (Story M.et.al., 2002) Therefore, determinants such as habits, attitudes, self-efficacy, barriers to change the meaning of "healthy" and "unhealthy" diet and food must be considered. However, the main purpose was to obtain the effect of dietary habits on body mass index of university students in different cultures as a comparative study among Egypt Saudi Arabia and Turkey.

\section{Literature review:}

Adolescence is a vulnerable period for developing unhealthy eating habits as well as a physically inactive lifestyle. While the family remains important, adolescence is an age characterized by increased mobility, independence from home and greater financial autonomy (WHO, 2005), which enables youngsters to purchase and consume their favorite food items and to spend their leisure time in many different ways. For example, during adolescence eating out of home becomes more frequent (Rolland-Cachera, et al., 2000) Eating behavior of adolescents can be influenced by both exogenous and endogenous factors. The most important exogenous factors are probably parents, peers, and the media. Gender, intellectual ability, self-concept, and personality are among the endogenous factors that may influence the eating behavior of adolescents (Bester $\mathrm{G}$, and Schnell ND. 2004).As with correlates of eating behaviors, gender, age and socio-demographic 
factors are also important descriptive or distal predictors for physical activity. Boys are consistently found to be more active than girls (Sallis, et al.,2000; Pate, et al., 2002; Trost, et al., 2002; Biddle, et al., 2004; Currie, et al., 2004).

In a random sample of 1682 teenagers in Scotland, Sweeting et al. (1994) found that overall changes in eating habits between 15 and 18 years were very slight, though females were more likely to have increased consumption of foods consistent with current recommendations. The authors concluded that dietary habits appear to be established in the mid-teens, by the age of 15 years, and are closely associated with the lifestyle.

Unhealthy eating behaviors often come together with physical inactivity, increasing the risk for developing health problems (Kvaavik, et al., 2004) In addition, numerous studies referred that there are associations between body weight and eating-related behaviors, including breakfast habits, family meals; nutritional status, emotional eating (Gail C.et. al.,2005), and binge eating, also culture and socioeconomic status play an important role in the development of eating behaviors (Tanofsky-Kraff M et al.2006). Dietary behaviors and practices or eating habits observed in adolescents may have detrimental consequences on their health. The adverse health consequences that may result from excessive intake of soft drinks and sweet drinks, fast foods consumption, inadequate intakes of fruits, vegetables, whole grain foods, and dairy products and other calcium-fortified foods; reduced levels of exercise ; and increasing obesity rates indicate a need to revisit the diet and lifestyle characteristics of this age group. (St-OngeMP. Et.al. 2003) Health care providers should work with families and adolescents to promote family meals, emphasizing turning the TV off at meals (Feldman S.2007).

Education can be provided to students to address individual level determinants and induce individual change processes. At the same time, school environments can be improved to support healthy eating and physical activity. School policies, qualified staff and incentives in the school's physical environment are other important factors amenable to change in order to improve health behavior. (Wechsler H.et.al.,2000, Kubik MY et al.,2003). In addition, evidence from reviews showed that educational interventions were most likely to show an effect on dietary behaviors. (Van Cauwenberghe E, et al., 2010)

However a pilot study conducted among high school students in Greece, promoting fruit and vegetable intake by providing 20-minute classroom sessions, workbooks and information for parents, was not effective for increasing fruit and vegetable intake (Hassapidou, 1997). Moreover the Teens Eating for Energy and Nutrition at Schools (TEENS) study was a 2-year intervention study conducted in American middle schools. The intervention included 10 classroom sessions, cafeteria promotion of fruit and vegetables and lower fat foods, and newsletters and home activities included in parent packs. At the end of the first intervention year, fruit and vegetable intake as well as food-choice scores (choice of lower fat versus higher fat foods) were improved as a result of the multi-component intervention (environmental + classroom + peer support). However, after 2 school years positive intervention effects were only seen for food choice score, but no effects on food intake were found (Lytle, et al., 2004). Hazzaa MH, (2009) stated that It is very critical that preventive strategies are implemented through schools and community-based programs, with involvement of health care providers, school teachers, community leaders, and policy makers, as well as parents. It confirmed that the school's nutrition and physical activity environment can be conceptualized as any external factor that could influence eating and physical activity behaviors of its students (Wechsler, et al., 2000).

On the other hand one study showed that like eating behaviors, non-authoritative parenting style was also positively associated with physical activity in adolescents (Schmitz, et al., 2002) 


\section{Methods and subjects:}

\section{Design and Sample}

A comparative cross sectional study was conducted in some colleges (Theoretical and applied) in universities at Egypt, Saudi Arabia and Turkey during the semester of 2013. A total number of 150 male and female students aged 19-26 years from each country had participated in the study after signing an approval form for each country. All of the participants were chosen by random sampling method by department and class years. The response rate among students was $97.2 \%$.

\section{Data Collection}

Self-administrated questionnaire and anthropometric measurements were used for data collection. The questionnaire was designed to evaluate socio-demographic characteristic, eating, drinking, food habits, and life style among college students, and its use in that respect had been standardized under the same conditions at study regions (Egypt, Saudi Arabia and Turkey).

Proceeding to filling out the questionnaire, the students were informed about the study and were given instructions on how to fill out the questionnaire correctly.

\section{Anthropometrics}

Weight and height were registered in light clothing and undressed feet. Weight was assessed to the nearest $0.1 \mathrm{~kg}$ (seca, max $200 \mathrm{~kg}$ ). Height to the nearest millimeter was measured using a wall-mountedstadmeterParticipants were asked to stand straight, with their heels against the wall. BMI was calculated by dividing the weight $(\mathrm{kg})$ by the height $(\mathrm{m})$ squared.

Table 1: $\operatorname{mass}(\mathrm{Kg}) /($ height $(\mathrm{m})) 2$ average

\begin{tabular}{|l|l|}
\hline BMI & $=$ mass $(\mathrm{Kg}) /($ height $(\mathrm{m})) 2$ \\
\hline less than 18.5: & Underweight \\
\hline 18- 25: & Normal weight \\
\hline 25 - 30: & Overweight \\
\hline over 30 & Obese \\
\hline
\end{tabular}

\section{Data Analysis:}

The Statistical Package for Social Sciences (SPSS Inc., Chicago, IL, USA) version 17 was used for data analysis. Results were expressed as frequency and percentage. All of the analyzed variables were non-parametric and were tested using Chi-squared tests. All reported $\mathrm{P}$ values were made on the basis of two-tailed tests. Differences were considered statistically significant at $\mathrm{P}$ value $<0.05$.

\section{Findings:}

\section{Descriptive analysis of the study sample:}

Socio-demographic data: Table 2 shows the socio-demographic characteristic of university students' participants in Egypt, Saudi Arabia and Turkey in terms of Gender, Age, Number of family members, Academic specialization and Average of family monthly income.

Table (2): Distribution of the participants according to socio-demographic characteristics:

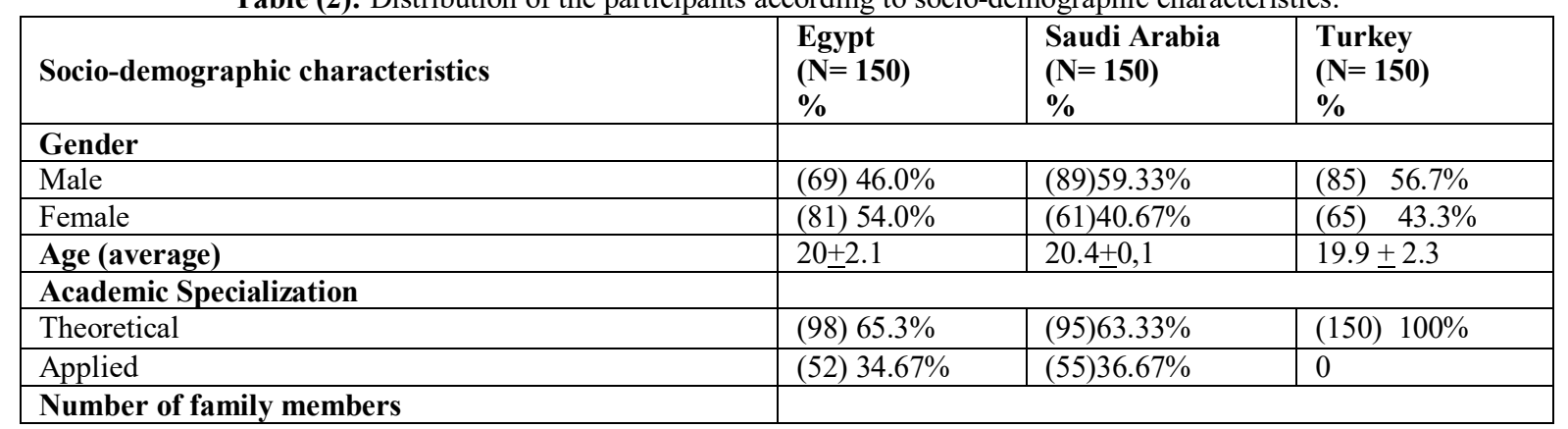


Influence of Dietary Habits of University Students on Body Mass Index (BMI)...

\begin{tabular}{|c|c|c|c|}
\hline Less than 3 (Less than or $=4$ ) & $(55) 36.6 \%$ & $(34) 22.67 \%$ & (10) $6.7 \%$ \\
\hline 4 to 6 (5 to 7$)$ & (84)56.0\% & (53)35.33\% & (59) $39.3 \%$ \\
\hline 6 and more $(8$ and more $)$ & (11) $7.33 \%$ & $(63) 42.00 \%$ & (81) $\quad 54.0 \%$ \\
\hline \multicolumn{4}{|l|}{ Average of family Monthly Income } \\
\hline less than $1000(\mathrm{LE}-\mathrm{SR}-\mathrm{TL})$ Low & (30) $20.0 \%$ & & (64) $42.7 \%$ \\
\hline 1000- 2000 (LE - SR -TL)Moderate & (76) $50.76 \%$ & & (62) $41.3 \%$ \\
\hline 2000-3000 (LE - SR -TL)High & $(34) 22.67 \%$. & & (17) $11.3 \%$ \\
\hline $3000(\mathrm{LE}-\mathrm{SR}-\mathrm{TL})$ and more & (10) $0.99 \%$ & & (7) $4.7 \%$ \\
\hline
\end{tabular}

It was observed that the majority of the studied samples were Female in Egypt (54.0\%), Male in Saudi Arabia (59.33\%), and Turkey (56.7\%). Moreover the majority of the Egyptian, Saudi Arabian and Turkish participants' academic specializations were theoretical $(65.3 \%, 63.33 \%$, and $100 \%$ respectively). More than half of the Egyptian sample (56.0\%) has family members between (4-6) persons while 43\% of Saudi sample Arabian and 54\% of Turkish sample have 6 or more family members. In terms of income data showed that $57.33 \%$ of Egyptian and $41.3 \%$ of Turkish sample were in moderate income with an average of 1000- $2000 \mathrm{LE} / \mathrm{TL}$ as for the Saudi Arabian sample $\%$ of the participants were in high income with an average of more than $3000 \mathrm{SR}$.

Table (3): Distribution of the participants according to eating pattern (food consumption):

\begin{tabular}{|c|c|c|c|c|}
\hline Participants eating pattern & $\begin{array}{l}\text { Egypt } \\
(\mathrm{N}=150)\end{array}$ & $\begin{array}{l}\text { Saudi Arabia } \\
(\mathrm{N}=) \\
\%\end{array}$ & $\begin{array}{l}\text { Turkey } \\
(\mathrm{N}=150 \quad) \\
\%\end{array}$ & $\begin{array}{l}P \\
\text { Value }\end{array}$ \\
\hline \multicolumn{5}{|l|}{ Main meal of the day } \\
\hline Breakfast & (33) $22.0 \%$ & (22) $14.67 \%$ & $(85) 56.7(\mathrm{~F})$ & \multirow{4}{*}{$0.02 *$} \\
\hline Lunch & (73) $48.7 \%$ & (74) $49.33 \%$ & (59) $39.3(\mathrm{~F})$ & \\
\hline Dinner & (44) $29.3 \%$ & (54)36.00\% & $(107) 71.3(\mathrm{~F})$ & \\
\hline $\mathrm{p}$ value & 0.172 & 0.074 & 0.085 & \\
\hline \multicolumn{5}{|l|}{ Eating breakfast daily } \\
\hline Yes & (27) $18.0 \%$ & $(12) 8.00 \%$ & (69) $46 \%$ & \multirow{4}{*}{$.00 *$} \\
\hline No & (92) $61.33 \%$ & $(98) 65.33 \%$ & (12) $8 \%$ & \\
\hline Sometimes & (31) $20.7 \%$ & (40)26.67\% & (69) 46 & \\
\hline $\mathrm{p}$ value & 0.191 & 0.142 & 0.078 & \\
\hline \multicolumn{5}{|l|}{ Eating snacks daily } \\
\hline Yes & (102) 68.0\% & $(105) 70.00 \%$ & (68) $45 \%$ & \multirow{4}{*}{.12} \\
\hline No & $(5) 3.33 \%$ & (16) $10.67 \%$ & (10) 6.7 & \\
\hline Sometimes & (43) $28.7 \%$ & (29) $19.33 \%$ & (72) 48 & \\
\hline $\mathrm{p}$ value & $0.001 *$ & $0.050^{*}$ & $0.000 *$ & \\
\hline \multicolumn{5}{|l|}{ Daily vegetables consumption } \\
\hline Yes & (22) $14.7 \%$ & (21)14.00\% & (55) $36.7 \%$ & \multirow{4}{*}{.46} \\
\hline No & $(86) 57.33 \%$ & $(86) 57.33 \%$ & $13.3 \%$ & \\
\hline SOMETIMES & (42) $28.0 \%$ & $(43) 28.67 \%$ & $(75) 50 \%$ & \\
\hline $\mathrm{p}$ value & 0.061 & $0.000^{*}$ & 0.010 & \\
\hline \multicolumn{5}{|l|}{ Daily fruits consumption } \\
\hline Yes & (21) $14.0 \%$ & (16) $10.67 \%$ & (50) 33.3 & \multirow{4}{*}{.21} \\
\hline No & (83) $55.3 \%$ & $(83) 55.33 \%$ & $\begin{array}{ll}(25) & 16.7\end{array}$ & \\
\hline Sometimes & (46) $30.7 \%$ & (51)34.00\% & (75) 50.0 & \\
\hline $\mathrm{p}$ value & 0.082 & 0.053 & 0.063 & \\
\hline \multicolumn{5}{|l|}{ Milk consumption: } \\
\hline Yes & (25) $16.7 \%$ & $(56) 37.33 \%$ & (18) 12 & \multirow[b]{2}{*}{.27} \\
\hline No & (83) $55.3 \%$ & $(76) 50.67 \%$ & (72) 48.0 & \\
\hline
\end{tabular}


F. Ü. Sosyal Bilimler Dergisi 2015-25/2

\begin{tabular}{|c|c|c|c|c|}
\hline Sometimes & (42) $28.0 \%$ & (18) $12.00 \%$ & (60) 40.0 & \\
\hline $\mathrm{p}$ value & 0.538 & 0.479 & $0.037 *$ & \\
\hline \multicolumn{5}{|c|}{ Meat consumption/ weekly } \\
\hline Yes & (97) $64.7 \%$ & (76)50.67\% & (91) 60.7 & \multirow{4}{*}{.42} \\
\hline No & (31) $20.7 \%$ & (11)7.33\% & (13) 8.7 & \\
\hline Sometimes & (22) $14.7 \%$ & (63) $42.00 \%$ & (46) 72.7 & \\
\hline $\mathrm{p}$ value & 0.108 & 0.341 & 0.415 & \\
\hline \multicolumn{5}{|c|}{ Fish consumption/ weekly } \\
\hline Yes & (46) $30.7 \%$ & $(32) 21.33 \%$ & $\begin{array}{|ll|}(32) & 21.3 \\
\end{array}$ & \multirow[b]{4}{*}{0.38} \\
\hline No & (69) $46.0 \%$ & $(84) 56.00 \%$ & $\begin{array}{|ll|}(57) & 38.0 \\
\end{array}$ & \\
\hline Sometimes & (35) $23.3 \%$ & (34) $22.67 \%$ & $\begin{array}{ll}(61) & 40.7\end{array}$ & \\
\hline $\mathrm{p}$ value & $0.018^{*}$ & 0.085 & $0.012 *$ & \\
\hline \multicolumn{5}{|c|}{ Fast foods consumption } \\
\hline Yes / Daily & (21) $14.0 \%$ & $(102) 68.00 \%$ & $\begin{array}{ll}(15) & 10.0\end{array}$ & \multirow[b]{5}{*}{$.03 *$} \\
\hline Yes / Weekly & $(75) 50.0 \%$ & $(113) 75.33 \%$ & 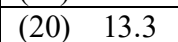 & \\
\hline Sometimes & (45) $30.0 \%$ & $(32) 21.33 \%$ & $\begin{array}{|ll|}(115) & 76.3 \\
\end{array}$ & \\
\hline No & (9) $6.0 \%$ & $(12) 8.00 \%$ & (o) 0.0 & \\
\hline $\mathrm{p}$ value & $0.016^{*}$ & $0.042 *$ & $0.039 *$ & \\
\hline \multicolumn{5}{|c|}{ Daily desserts consumption } \\
\hline Yes & (89) $59.3 \%$ & $(95) 63.33 \%$ & \begin{tabular}{|ll}
$(30)$ & 20.0 \\
\end{tabular} & \multirow[b]{4}{*}{0.26} \\
\hline No & $(17) 11.3 \%$ & $(22) 14.67 \%$ & $\begin{array}{|ll|}(28) & 18.7 \\
\end{array}$ & \\
\hline Sometimes & (44) $29.3 \%$ & $(33) 22.00 \%$ & $\begin{array}{ll}(92) & 61.3 \\
\end{array}$ & \\
\hline $\mathrm{p}$ value & $0.050 *$ & $0.000^{*}$ & $0.010^{*}$ & \\
\hline \multicolumn{5}{|c|}{ Daily soft drinks consumption } \\
\hline Yes & $(95) 63.3 \%$ & (93) $62.00 \%$ & $\begin{array}{|ll|}(83) & 55.3 \\
\end{array}$ & \multirow{4}{*}{0.25} \\
\hline No & (8) $5.3 \%$ & $(25) 16.67 \%$ & $\begin{array}{|ll|}(33) & 22.0 \\
\end{array}$ & \\
\hline Sometimes & (44) $29.3 \%$ & (32)21.33\% & \begin{tabular}{|ll}
$(34)$ & 22.7
\end{tabular} & \\
\hline $\mathrm{p}$ value & $0.008^{*}$ & $0.015^{*}$ & $0.002 *$ & \\
\hline
\end{tabular}

F) Frequency: selected multiple answers

\section{1- Participants' Dietary pattern:}

The results shown in Table 3 revealed that the main meal for the majority of Egyptian (48.7\%) and Saudi Arabian (49.33\%) was lunch while in Turkey the main meal was dinner (71.3\%). Despite all of breakfast's benefits, it might be the meal that is most often skipped. It is a common habit between both children and adults to skip breakfast or intake of a breakfast with poor nutritional value. Breakfast omission has an effect on lifestyles factors including eating habits. (Aslam and Monazza , 2010). The Saudi population used to consume two meals per day including breakfast, together with frequent snacks and fried food consumption. (Al-Rethaiaa, Fahmy, \& AlShwaiyat, 2010).

With regard to eating breakfast, nearly half of the Turkish sample was eating breakfast daily (46\%) whereas more than half of Egyptian (61.33\%) and Saudi Arabian samples (65.33\%) didn't eat breakfast daily. Research studies and reviews indicate that breakfast skipping is highly prevalent among adolescents in the United States and Europe (Rampersaud GC ET AL., 2005) as well as in many Arab countries (Abalkhail B, Shawky S 2002., Mikki N ET AL., 2010). Samuel,(2002) points out that adolescents who skip breakfast are missing an opportunity to boost their nutrient intake, which has a negative effect on their learning performance and academic achievement.

In relation to eating snacks daily, the majority of Egyptian (68.0\%) and Saudi Arabian $(70.00 \%)$ participants preferred eating snacks daily and nearly the half $(48 \%)$ of the Turkish sample preferred eating snacks sometimes. Food choices made by adolescents while snacking tend to be high in sugar, sodium, and fat, while relatively low in vitamins and minerals which increase risk for 
Influence of Dietary Habits of University Students on Body Mass Index (BMI)... developing obesity, heart disease, osteoporosis, dental cavities, and various types of cancer. (Eumark-Sztainer D et al. 2002). In a study for Spanos and Hankey (2010) examined the habitual meal and snaking patterns of university students and found no correlation between BMI and snacking. Although increased snacks consumption is often accused for increased prevalence of obesity, yet, a clear cut relation between snacking and BMI is still unsettled. On the other hand, it is reported that snacks consumption may contribute to a positive energy balance and increased body weight (De Graaf,2006).

In terms of eating vegetables, the result showed that more than half of the Egyptian (57.33\%) and Saudi Arabian (57.33\%) samples didn't eat vegetables daily whereas 50\% of Turkish sample eating vegetables sometimes, in the meantime same results were obtained in terms of eating fruits with the same percentage (55.3\%) for Egypt and Saudi Arabia compared to 50.0\% for Turkey. It means that half of the student's samples do not eat a diet rich in fruits and vegetables which is considered to be particularly important during adolescence due to the high nutrient needs in this rapid period of growth and development. Furthermore, the development of healthy eating patterns during adolescence, including an adequate fruit and vegetable intake, may lead to continued healthy eating patterns in adulthood. (Dianne Neumark-Sztainer et al.2003). It is reported that high consumption of vegetables and fruits are low in energy density because of their high water and fiber content. Therefore, adding them to a diet reduces its overall energy intake, thus, helping in weight reduction (Rolls et al .,2004).

In terms of drinking milk daily the results indicated that $16.7 \%, 37.33 \%, 12 \%$ of Egyptian, Saudi Arabian and Turkish samples respectively drinking milk daily and 28.8\%, $12.0 \%, 40.0 \%$ sometimes drink milk, and about $55.3 \%, 50.67 \%, 48.0 \%$ didn't drink milk daily with the same arrangement. Further study on large number of subjects with long term advice to consume adequate milk and observe the beneficial effects on health due to the improvement in vitamin B-12 status is needed. Then promotion of an adequate milk intake would be a good therapeutic strategy. ( Sadanand Naik et. al 2013)

Table (2) represented the frequently consumption of meat weekly, among majority of the studied samples in Egypt, Saudi Arabia and Turkey (64.7\%, 50.67\% and 60.7\% respectively). As for the increase in the consumption of meat weekly, it is reported that the content of saturated fatty acids in animal fats contributes to heart disease and atherosclerosis, Recent studies also showed that frequent red meat eaters face increase in weight and be at high risk for $\mathrm{f}$ colon cancer as those who less consumed, also thought to increase the risks factors of arthritis and endometriosis. The results suggest also that red meat consumption, particularly processed red meat, is associated with an increased risk of type 2 diabetesT2D. (An Pan et. al., 2011)

The results showed clearly the low intake of fish per week among the three countries. In both Egypt and Saudi Arabia more than forty percent of the samples $(46.0 \%, 56.00 \%$ respectively) didn't consume fish weekly, In turkey $40.7 \%$ of participants sometimes consume fish weekly.

The consumption of fish tend to be low so that may reduce the health benefits of fish consumption. Some studies have associated benefits of consuming fish with healthy brain, prevention of CVD , however, fish consumption was related to a reduced risk of total mortality. ${ }^{\mathrm{i}}$

The trend of fast foods consumption for all countries exposed that most of the studied sample (50.0\%) in Egypt consumed fast food weekly, as well as in Saudi Arabia $68.00 \%$ of total sample consumed fast food daily, while in Turkey the majority of participants (76.3\%) sometimes consumed fast food. University Students often select fast food due to its palatability, availability and convenience. Surprisingly, our study found that only $21.2 \%$ of respondents consumed fast food often. (Chin and Nasir, 2009)

Moy et al., (2009) reported that $60-70 \%$ of primary school students were fond of fast food. However, our study also found that majority of respondents among three countries consumed fried food at least twice a week or more, which was in line with the results of a previous study. 


\section{F. U. Sosyal Bilimler Dergisi 2015-25/2}

The previous studies showed that the fast foods are rich sources of saturated fatty acids and trans fatty acids. Fast food consumption can lead to hyperinsulinemia and develop insulin resistance, High energy density, high glycaemic index, and saturated fatty acid composition of fast foods may increase the prevalence of obesity and cardiovascular risk factors. ( Isganaitis $\mathrm{E}$ and Lustig RH 2005).

Regarding to daily desserts consumption, the majority of studied samples for all countries consumed desserts daily in Egypt, Saudi Arabia and Turkey (59.3\%, 63.33\%, and 61.3\% respectively). The increase of consumption desserts refers to the increase of consumption of sugars since there are large quantities of sugar in most of the desserts which have been eaten. However, sugar enters the body as energy and without enough exercise will turn into fat very quickly. This unavoidably leads to weight gain. And also, empty calories from added sugars and solid fats contribute to $40 \%$ of daily calories for children and adolescents aged 2-18 years, affecting the overall quality of their diets. Approximately half of these empty calories formed from the consumption of soda, fruit drinks, dairy desserts, grain desserts, pizza, and whole milk which may have harmful effects on health. . ( Isganaitis E and Lustig RH 2005).

Table (3), demonstrates the results of daily soft drinks consumption, the majority of the studied samples through the three countries consumed soft drinks daily $(63.3 \%, 62.0 \%, 55.3 \%$ respectively). At present, there is a real concern about the increase of unhealthy dietary habits, including skipping breakfast and greater consumption of sweetened soft drinks by young people, and the possible role of these habits in the pathogenesis of childhood obesity (Brown CM et al 2008, Croezen S et al., 2009)

\section{Distribution of the participants according to type of favorite foods:}

Table (4): Distribution of the participants according to type of favorite foods:

\begin{tabular}{|c|c|c|c|c|}
\hline & $\begin{array}{l}\text { Egypt } \\
(\mathrm{N}=150) \\
\%\end{array}$ & $\begin{array}{l}\text { Saudi Arabia } \\
(\mathrm{N}=150 \quad) \\
\%\end{array}$ & $\begin{array}{l}\text { Turkey } \\
(\mathrm{N}=150)\end{array}$ & $\begin{array}{l}\mathbf{P} \\
\text { Value }\end{array}$ \\
\hline \multicolumn{5}{|l|}{ Daily meals: } \\
\hline Red Meat & (89) $59.3 \%$ & (92) 61.33\% & (62) 41.3 & \multirow[b]{6}{*}{$0.011 *$} \\
\hline Poultry & (63) $42.0 \%$ & (84) $56.00 \%$ & (59) 39.3 & \\
\hline Fish & (25) $16.7 \%$ & (32) $21.33 \%$ & (12) 8 & \\
\hline Vegetables & (21) $14.0 \%$ & (45) $30.00 \%$ & ( 70 ) 46.7 & \\
\hline Milk and milk products & (75) $50.0 \%$ & (44) $29.33 \%$ & $(22) 14.7$ & \\
\hline Pasta & (53) $35.3 \%$ & (38) $25.33 \%$ & (49) 32.7 & \\
\hline $\mathrm{p}$ value & 0.003 & 0.081 & 0.171 & \\
\hline \multicolumn{5}{|l|}{ Cooking methods: } \\
\hline Frying & (62) $41.3 \%$ & $458) 45.33 \%$ & (79) 52.7 & \multirow[b]{4}{*}{0.37} \\
\hline Boiling & (21) $14.0 \%$ & (21) $14.00 \%$ & (32) 21.3 & \\
\hline Sautéed & (35) $23.3 \%$ & (29) $19.33 \%$ & (34) 22.7 & \\
\hline Grilling & (32) $21.33 \%$ & (32) $21.33 \%$ & $(67) \quad 44.7$ & \\
\hline $\mathrm{p}$ value & 0.085 & 0.023 & 0.082 & \\
\hline \multicolumn{5}{|l|}{ Favourite Snacks } \\
\hline Vegetables & (25) $16.7 \%$ & $15,10.00 \%$ & (56) 34.3 & \\
\hline Fruits & $(47) 31.3 \%$ & (19) $12.67 \%$ & (77) 51.3 & \\
\hline Sandwich & (68) $45.3 \%$ & (21) $14.00 \%$ & (23) 15.3 & \\
\hline dough products & (76) $50.7 \%$ & (39) $26.00 \%$ & $\begin{array}{ll}(27) & 18 \\
\end{array}$ & \\
\hline Biscuits & $(35) 23.3 \%$ & (48) $32.00 \%$ & (45) 30 & \\
\hline Chocolate & $(86) 57.3 \%$ & (52) $34.67 \%$ & (47) 31.3 & \\
\hline Milk & (25) $16.7 \%$ & (18) $12.00 \%$ & (23) 15.3 & \\
\hline Chips & $80.0 \%$ & (78) $52.00 \%$ & $\begin{array}{ll}(71) & 47.3 \\
\end{array}$ & \\
\hline Fresh Juice & (56) $37.3 \%$ & (29) $19.33 \%$ & 27.3 & 0.40 \\
\hline
\end{tabular}


Influence of Dietary Habits of University Students on Body Mass Index (BMI)...

\begin{tabular}{|c|c|c|c|c|}
\hline Fizzy drinks & $(96) 64.0 \%$ & (64) $42.67 \%$ & (57) 38 & \\
\hline Nuts & $(38) 25.33 \%$ & (73) $48.67 \%$ & $\begin{array}{ll}(58) & 38.7\end{array}$ & \\
\hline $\mathrm{p}$ value & 0.875 & 0.356 & 0.089 & \\
\hline \multicolumn{5}{|c|}{ Favourite drinks: } \\
\hline Tea & (98) $65.33 \%$ & (76)50.67\% & $\begin{array}{ll}(85) & 56.7\end{array}$ & \multirow{5}{*}{0.62} \\
\hline Coffee & $(75) 50 \%$ & (98) $65.33 \%$ & $\begin{array}{ll}44) & 29.3\end{array}$ & \\
\hline Fresh juice & $(24) 16.0 \%$ & $(28) 18.67 \%$ & ( 65$) \quad 43.3$ & \\
\hline Canned juice & (36) $24 \%$ & $(32) 21.33 \%$ & (20) 13.3 & \\
\hline $\mathrm{p}$ value & $0.001^{*}$ & 0.081 & $0.025^{*}$ & \\
\hline \multicolumn{5}{|c|}{ Favourite food while watching TV or computer: } \\
\hline Main meal & $(86) 57 \%$ & (52) $34.67 \%$ & (15) 10 & \\
\hline Sandwiches & (35) $23.33 \%$ & (28) $18.67 \%$ & (6) 4 & \\
\hline Fizzy drinks & (53) 35.33 & (98) 65.33\% & ( 59) 39.3 & \\
\hline Fresh juice & (29) $19.33 \%$ & (24)16.00\% & $(39) 26$ & \\
\hline Fast foods & (69)46.00\% & (15) $10.00 \%$ & $\begin{array}{ll}(19) & 12.7 \\
\end{array}$ & \\
\hline Desserts & $(12) 8 \%$ & (37) $24.67 \%$ & $\begin{array}{ll}(28) & 18.6 \\
\end{array}$ & \\
\hline Nuts & (64) $42.67 \%$ & (49) $32.67 \%$ & $(101) 67.3$ & 0.75 \\
\hline $\mathrm{p}$ value & $0.028^{*}$ & $0.000^{*}$ & $0.001 *$ & \\
\hline
\end{tabular}

F) Frequency: selected multiple answers

It is illustrated in Table (4) that considering main dishes in daily meals that $59.3 \%$ and 61.33\% respectively of the studied sample in Egypt and Saudi Arabia responded the red meat were the main food in daily meals, but in Turkey vegetables were the main food in daily meals for $46.7 \%$ of the sample, followed by red meat $41.3 \%$. Several, but not all, epidemiological and experimental studies suggest that a high intake of meat, especially red meat is associated with increased colorectal cancer risk. (Eunjung Kim et. al.2013).

As for the cooking methods the same trend was observed between the three countries, The Frying method was the preferred cooking method for the majority of the studied samples in Egypt, Saudi Arabia , and Turkey (41.3\% , 45.33\% and 52.7 \% respectively). Instead of the good taste of the fried food it has a lot of harmful effects on health. Knowledge of healthy diets among school students was inadequate like high consumption of unsaturated fats and cholesterol rich foods. However, it is recommended that health education and information about healthy eating habits and lifestyle should be included in school curriculum (Al-Almaie, 2005).

In Egypt the most favorable Snacks were Chips $80.0 \%$, followed by Fizzy drinks $64.0 \%$, Chocolate 57.3\%, dough products 50.7\% , Sandwich 45.3\% , Fresh Juice 37.3\% , Fruits $31.3 \%$ then milk and vegetables 16.7\% . Also In Saudi Arabia Chips was the most favorable snacks for the majority of studied sample $52.00 \%$, followed by Fizzy drinks $42.67 \%$, Nuts $48.67 \%$, Chocolate $34.67 \%$, Biscuits $32.00 \%$, dough products $26.00 \%$, Fresh Juice $19.33 \%$, Milk and fruits $12.67 \%$ then Vegetables $10.00 \%$. In turkey, the most favorable snack was Fruits $51.3 \%$, followed by Chips $47.3 \%$, Nuts $38.7 \%$, Fizzy drinks 38\%, Chocolate 31.3\%, Biscuits 30\%, Fresh Juice $27.3 \%$, then Sandwich and Milk 15.3\%.

Platat et al. (2006) reported a significant positive association with the intake of French fries, potato chips and sweetened drinks and a negative association with the high consumption of fruit and vegetables. The National survey data reported that $88 \%$ of adolescents consume at least one snack per day, with a range of 1 to 7.(FeldmanS et al 2007). Snacks account for $25-33 \%$ of daily energy intake among adolescents. Food choices for adolescents like snacking tend to be high in sugar, sodium, and fat, while relatively low in vitamins and minerals which increased risk for developing obesity, heart disease, osteoporosis, dental cavities, and various types of cancer (Eumark, et al 2010).

The data referred that the most favorite drink for the majority of studied sample in Egypt and Turkey were tea for 50\% and 56.7\%, In Saudi Arabia coffee was the favorite drink for most of 


\section{F. U. Sosyal Bilimler Dergisi 2015-25/2}

studied sample (65.33\%). The trend for the countries was the consumption of tea and coffee which have health benefits depending on the quantities and add sugars per day. The resent studies recommended that, drinking sugar-sweetened beverages can result in weight gain, overweight, and obesity. (Dietary Guidelines2002)

It is observed that the favorite food consumed while watching TV or computer were Main meal (57\%), then Fast food (46.0\%) and nuts (42\%) in Egypt ; Fizzy drinks (65.33\%), then Main meals (34.67\%) and Nuts (32.67) and In Saudi Arabia. In Turkey the same trend was observed as that the Nuts (67.3\%), fizzy drinks (39.3) and Fresh juice (26\%) were consumed. The recent studies showed that watching television during family meals was associated with poorer dietary quality among adolescents. And it recommended to work with families and adolescents to promote family meals, emphasizing turning the TV off at meals. (FeldmanS et al,2007)

\section{Distribution of the participants according to BMI:}

Table (5): Distribution of the participants according to BMI

\begin{tabular}{|l|l|l|l|}
\hline Health status & $\begin{array}{l}\text { Egypt } \\
\mathbf{( N = 1 5 0} \\
\text { mean_SD }\end{array}$ & $\begin{array}{l}\text { Saudi Arabia } \\
\text { (N=150 ) } \\
\text { mean_SD }\end{array}$ & $\begin{array}{l}\text { Turkey } \\
\text { (N= 150 }) \\
\text { mean_SD }\end{array}$ \\
\hline BM I (kg/m2) & & & \\
\hline Underweight & $(29) 19.33 \%$ & $(65) 43.33 \%$ & $(13) 8.7$ \\
\hline Normal weight & $(33) 22.0 \%$ & $(38) 25.33 \%$ & $(113) 75.3$ \\
\hline Over weight & $(76) 50.67 \%$ & $(31) 20.67 \%$ & $(21) 14.0$ \\
\hline Morbid obesity & $(12) 8.00 \%$ & $(16) 10.67 \%$ & $(3) 2.0$ \\
\hline
\end{tabular}

Table (5) illustrates the classified results for BMI categories, which indicates that half of the studied sample in Egypt were overweight (50.67\%) whereas in Saudi Arabia (43.33\%) were underweight while the most sample (75.3\%) in Turkish sample were normal weight.

\section{Association between eating habits and deferent cultures:}

The purpose of this study was to assess eating habits for college students in three different cultures Egypt, Turkey and KSA, and also to evaluate the effects of eating pattern for the cultures among the studied BMI categories underweight, overweight, normal weight, and morbid obesity for each country using Pearson correlation test $p$ value $\geq 0.05$.

The results indicated that there are significant differences between three countries in type of main meal of the day, eating breakfast, weekly meat consumption, daily meals, and favorite food while watching TV or computer $\mathrm{p}$ value $\geq 0.05$.

And there are non-significant differences between three cultures for Daily consumption of snacks, vegetables, milk; weekly consumption of fish, fast foods, desserts and soft drinks; cooking methods, favorite Snacks, favorite drinks, $p$ value $\geq 0.05$.

\section{Association between the eating habits among BMI Categories in each culture:}

Regarding to evaluating the effects of eating pattern for the cultures among the studied BMI categories underweight, overweight, normal weight, and morbid obesity for each country In Egypt : There are a Significant differences between the BMI categories of Eating snacks daily, weekly Fish consumption, Fast foods consumption, Daily desserts consumption, Daily soft drinks consumption, Daily meals, Cooking methods, Favorite drinks, and Favorite food while watching TV or computer $p$ value $\geq 0.05$.

Further there are non- significant differences between the BMI categories of consumers for, Daily main meal of the day, Eating breakfast, vegetables consumption, fruits consumption, Milk consumption, weekly Meat consumption, Cooking methods, and favorite Snacks p value $\geq 0.05$. 
KSA:

Significant differences between the BMI categories of daily Eating snacks, vegetables, fruits, Fast foods, desserts, and soft drinks consumption, also Cooking methods, Favorite drinks, and Favorite food while watching TV or computer $p$ value $\geq 0.05$.

Non- significant differences between the BMI categories of consumers for daily Main meal, eating breakfast, Milk consumption, weekly Meat consumption, and Fish consumption $p$ value $\geq$ 0.05 .

\section{Turkey:}

Significant differences between the BMI categories daily Eating snacks, vegetables consumption, Milk consumption, desserts consumption also weekly Fish consumption, Fast foods consumption and Daily soft drinks consumption $p$ value $\geq 0.05$.

Non- significant differences between BMI categories of consumers for Main meal of the day, Eating breakfast daily, Daily fruits consumption, weekly Meat consumption, Daily meals , Cooking methods and Favorite Snacks $\mathrm{p}$ value $\geq 0.05$.

\section{Conclusion:}

In general, most of the students had unhealthy eating habits like not eating breakfast daily in both Egypt and KSA except Turkey, eating snacks, intake of desserts and soft drinks daily, increasing the consumption of fast foods specially in KSA and Egypt, The red meat the most sources of proteins which consumed daily, Frying the most favorite cooking methods, The types of snacks which most consumed were chips, fuzzy drinks and chocolate in Egypt, chips, nuts and fuzzy drinks in KSA, fruits, chips ,nuts and fuzzy drinks. The tea was the most favorite drink in all cultures. And the most favorite consumed foods during watching TV Fast food, nuts and fuzzy drinks in all cultures. All the observed unhealthy eating habits considered as an indicators for incidence of most chronic diseases in the communities.

\section{Recommendations:}

Eating habits and daily consumption of foods is one of the important factors of determinants of the healthy nutritional status among college students. Nutritional educational programs among college students should be encouraged to promote healthier eating habits and lifestyles, as well as adhering to the cultures' eating habits.

\section{References}

Abalkhail B, Shawky S: (2002): Prevalence of daily breakfast intake, iron deficiency anaemia and awareness of being anaemic among Saudi school students. Int J Food Sci Nutr, 53:519-528.

Al-Almaie, S. (2005). Knowledge of healthy diets among adolescents in eastern Saudi Arabia. Ann.Saudi.Med., 25, 294-298.

Al-Rethaiaa , A, S, Fahmy A, A and Al-Shwaiyat N, M. ,( 2010). Obesity and eating habits among college students in Saudi Arabia: a cross sectional study. Nutrition Journal , 9:39.

An Pan, Qi Sun, Adam M Bernstein, Matthias B Schulze, JoAnn E Manson, Walter C Willett, and Frank BHu (2011):Red meat consumption and risk of type 2 diabetes: 3 cohorts of US adults and an updated metaanalysis. Am J Clin Nutr October, vol. 94 no. 4 1088-1096

Aslam and Monazza. (2010) .Parental education and child health, understanding the pathways of impact in Pakistan. Oxford : CSAE.

Bester G,andSchnell ND. (2004) Endogenous factors that relate to the eating habits of adolescents. South African Journal of Education .; Vol 24(3) 189-193.

Biddle, S. J. H., Gorely, T., \& Stensel, D. J. (2004).Health-enhancing physical activity and sedentary behaviour in children and adolescents. Journal of Sports Sciences, 22(8), 679-701. 


\section{F. U. Sosyal Bilimler Dergisi 2015-25/2}

Brown CM, Dulloo AG, Montani JP: (2008).Sugary drinks in the pathogenesis of obesity and cardiovascular diseases. Int J Obes (Lond), 32(Suppl 6): S28-S34.

Chin YS \& Mohd Nasir MT (2009). Eating behaviours among female adolescents in Kuantan

district, Pahang, Malaysia.Pakistan J Nutr 8(4): 425-432

Croezen S, Visscher TL, Ter Bogt NC, Veling ML, Haveman-Nies A: (2009).Skipping breakfast, alcohol consumption and physical inactivity as risk factors for overweight and obesity in adolescents: results of the E-MOVO project. Eur J Clin Nutr, 63:405-412.

Currie, C., Roberts, C., Morgan, A., Smith, R.,Settertobulte, W., Samdal, O., \& Barnekow Rasmussen, V. (2004). Health Behaviour in School-Aged children (HBSC) study: international report from the 2001/2002 survey (No. 4). Copenhagen: World Health Organization. 23.

De Graaf C. (2006): Effects of snacks on energy intake: An evolutionary perspective. Appetite, 47:18-

Dianne Neumark-Sztainer et al, (2003) Correlates of fruit and vegetable intake among dolescents Findings from Project EAT, Preventive Medicine 37, 198-208.

Dietary Guidelines Advisory Committee. (2010): Report of the Dietary Guidelines Advisory Committee on the Dietary Guidelines for Americans, to the Secretary of Agriculture and the Secretary of Health and Human Services. Washington, DC: U.S. Department of Agriculture.

Eumark-Sztainer D et al (2002):: Overweight status and eating patterns among adolescents: Where do youth stand in comparison to the Healthy People 2010 Objectives? Am J Public Health, 92:844-851.

Eunjung Kim,Desire Coelho and François Blachier. (2013) Review of the association between meat consumption and risk of colorectal cancer. Nutrition Research.Volume 33, Issue 12, December 2013, Pages 983-994.

FeldmanS et al, (2007): Associations between Watching TV during Family Meals and Dietary Intake Among Adolescents'NutrEducBehav.;39:257-263.

Gail C. , Mark A. , Beverly L., Judi A. \& Jordan D. , (2005) Breakfast habits, nutritional status, bodyweight, and academic performance in children and adolescents. J Am Diet Assoc.;105:743-760.

Hassapidou, M. N., Fotiadou, E., \& Maglara, E. (1997). A nutrition intervention programme for lower secondary schools in Greece. Health Education Journal, 56, 134-144.

Hazzaa MH, et .al.,(2009) Prevalence and trends in obesity and physical inactivity among Saudi children and adolescents: a growing public health challenge International Journal of Paediatric Obesity. ;(4), Issue S3 September : 6 - 14 .

Health, United States (2005). The 29th report on the health status of the Nation and ... compiled by the National Center for Health Statistics (NCHS),

Heilman, E.. (1998) The struggle for self: Power and identity in adolescent girls. Youth and Society.;30 (2), 182-208.

Isganaitis E, Lustig RH. (2005) Fast food, central nervous system insulin resistance,and obesity.Arteriosclerosis, Thrombosis, and Vascular Biology;25(12):2451-2462.

Kubik MY, Lytle LA, Hannan PJ, et al., (2003). The association of the school food environment with dietary behaviors of young adolescents. American journal of public health.; 93(7):1168-1173.

Kvaavik, E., Student, P. D., Meyer, H. E., \& Tverdal, A. (2004). Food habits, physical activity and body mass index in relation to smoking status in 40-42 year old Norwegian women and men. Preventive Medicine, $38(1), 1-5$.

Lytle, L. A., Murray, D. M., Perry, C. L., Story, M., Birnbaum, A. S., Kubik, M. Y., \& Varnell, S. (2004). School-based approaches to affect adolescents' diets: Results from the TEENS study. Health Education \& Behavior, 31(2), 270-287. 
Influence of Dietary Habits of University Students on Body Mass Index (BMI)...

Mikki N, Abdul-Rahim HF, Shi Z, Holmboe-Ottesen G: Dietary habits of Palestinian adolescents and associated sociodemographic characteristics in Ramallah, Nablus and Hebron governorates. Public Health Nutr 2010, 13(9):1419-1429.

Moy, AD, Howard, WR, Bray, SG, Trull, TW (2009). Reduced calcification in modern Southern Ocean planktonic foraminifera. Nature Geoscience 2, 276-280.

National Center for Health Statistics Health, United States (NCHS) (2005), Trends in the Health of Americans Hyattsville, Maryland: 2005

Niciforovic-Surkovic O, Kvrgic S, Ac-Nikolic E: (2002) Knowledge of nutrition and nutritional behavior of schoolchildren and their parents. in Vojvodina. Med Pregl 55:465-469.

Pate, R. R., Freedson, P. S., Sallis, J. F., Taylor, W.C., Sirard, J., Trost, S. G., Dowda, M. (2002). Compliance with physical activity guidelines: Prevalence in a population of children and youth. Annals of Epidemiology, 12(5), 303-308.

Platat C, Perrin AE, Oujaa M, Wagner A, Haan MC, Schlienger JL, Simon C. ( 2006)Diet and physical activity profiles in French preadolescents. Br J Nutr, 96:501-507.

Prell HC, Berg MC, Jonsson LM, Lissner L.(2005) : A school-based intervention to promote dietary change. J Adolesc Health 36:529-534.

Rampersaud GC, Pereira MA, Girard BL, Adams J, Metzl JD: (2005).Breakfast habits, nutritional status, body weight, and academic performance in children and adolescents. J Am Diet Assoc, 105:743-760.

Rolland-Cachera, M. F., Bellisle, F., \& Deheeger,M. (2000). Nutritional status and food intake in adolescents living in Western Europe. European Journal of Clinical Nutrition, 54, S41-S46.

Rolls BJ, Ello-Martin JA, Tohill BC: What Can Intervention Studies Tell Us about the Relationship between Fruit and Vegetables Consumption and Weight Management? Nutr Rev 2004, 62(1):1-17.

Sadanand Naik, Vijayshri Bhide, Ashish Babhulkar, Namita Mahalle, Sonali Parab, Ravi Thakre and Mohan Kulkarni.(2013): Daily milk intake improves vitamin B-12 status in young vegetarian Indians: an intervention trial. Nutrition Journal, 12:136.

Sallis, J. F., Prochaska, J. J., \& Taylor, W. C.(2000). A review of correlates of physical activity of children and adolescents. Medicine and Science in Sports and Exercise, 32(5), 963-975.

Samuel P. Are Your Kids Tempted To Skip Breakfast? Here's Some Food for Thought. Our Children.2002; 28:11.

Schmitz, K. H., Lytle, L. A., Phillips, G. A., Murray, D. M., Birnbaum, A. S., \& Kubik, M.Y. (2002). Psychosocial correlates of physical activity and sedentary leisure habits in young adolescents: The teens eating for energy and nutrition at school study. Preventive Medicine, 34(2), 266-278.

Schmitz, K. H., Lytle, L. A., Phillips, G. A., Murray, D. M., Birnbaum, A. S., \& Kubik, M. Y. (2002). Psychosocial correlates of physical activity and sedentary leisure habits in young adolescents: The teens eating for energy and nutrition at school study. Preventive Medicine,34(2), 266-278.

Spanos D, Hankey CR. (2010): The habitual meal and snacking patterns of university students in two countries and their use of vending machines. J Hum Nutr Diet, 23:102-107.

St-OngeMP, Keller KL, Heymsfield SB. (2003) Changes in childhood food consumption patterns: A cause for concern in light of increasing body weights. Am J Clin Nutr.; 78:1068-1073.

Story M, Neumark-Sztainer D, French S, (2002) Individual and environmental influences on adolescent eating behaviors. J Am Diet Assoc 102(3 Suppl):S40-S51.

Sweeting H, Anderson A, West P.(1994): Socio-demographic correlates of dietary habits in mid to late adolescence. Eur J Clin Nutr 48:736-748.

Tanofsky-Kraff M et al. (2006) A prospective study of psychological predictors of body fat gain among children at high risk for adult obesity. Pediatrics.;117: 1203-1209. 
Trost, S. G., Pate, R. R., Sallis, J. F., Freedson, P.S., Taylor, W. C., Dowda, M., \& Sirard, J. (2002). Age and gender differences in objectively measured physical activity in youth. Medicine and Science in Sports and Exercise, 34(2), 350-355.

Van Cauwenberghe E, Maes L, Spittaels H, et al., (2010) Effectiveness of school-based interventions in Europe to promote healthy nutrition in children and adolescents: systematic review of published and 'grey' literature. The British journal of nutrition. 1 03(6):781-797.

Wechsler H, Devereaux R, Davis M, Collins J.(2000): Using the School Environment to Promote Physical Activity and Healthy Eating. Prev Med.;31 :5121-5137.

Wechsler, H., Devereaux, R. S., Davis, M., \& Collins, J. (2000). Using the school environment to promote physical activity and healthy eating. Preventive Medicine, 31(2), S121-S137.

Wikipedia, the free encyclopedia

World Health Organization. (2005) .European Strategy for Child and Adolescent Health and development.WHO Regional Committee for Europe. Copenhagen,.

World Health Organization. Action for Adolescent Health. Geneva, 1997. 